\title{
Impact of some demographic parameters on leisure time and body weight
}

\section{DOI: http://doi.org/10.26758/7.1.12}

Cornelia Rada

"Francisc I. Rainer" Anthropology Institute of the Romanian Academy, Bucharest, E-mail: corneliarada@yahoo.com

\begin{abstract}
Objectives. This study aims to determine the variability of the preferred way of spending leisure time (LT), classification according to Body mass index (BMI) and the interest in the control of body weight $(\mathrm{BW})$, in relation to age, gender, place of residence and education within a Romanian sample.

Material and methods. Questionnaire data were obtained during 2011 and 2012 from 497 respondents aged 35-74. The sample was stratified to produce a well-balanced representation of place of residence, gender, age, and education level. The Pearson chi-square test was performed using the SPSS-18 statistical program.

Results. In the whole sample, most people spend "often" LT watching TV, watching rented movies, listening to tapes, CDs $(38.8 \%)$. Less than $8 \%$ practice "often" a sport, go to theater, cinema, concerts, exhibitions. BMI classification indicates $43.3 \%$ normal weight, $39.2 \%$ overweight, $16.9 \%$ obese, and $0.6 \%$ underweight. It has been identified that: with age the proportion of people controlling BW decreases, women and urban subjects control their BW more frequently $(\mathrm{p}<0.05)$, spending LT watching TV prevails, the older people spend more LT this way in comparison to young people and men are more likely than women to participate in sports, exercise. The higher percentage of obesity in 50-59 age group and of overweight beginning with the age of 60 suggests that weight gain rises with age and at the same time that the prevalence of obesity increases with age to peak at about 60 years.
\end{abstract}

Conclusions. The most important variable in promoting public health programs is age. These low percentages of leisure-time physical activity require urgent actions.

Keywords: spending leisure time, Body mass index, sedentariness.

\section{Introduction}

A definition of leisure time (LT) is based on what people consider leisure activities, "such as watching TV, participating in sports or exercise, reading, watching movies, etc. Eventually, LT can be defined as a state of mind, meaning engaging in agreeable or enjoyable" (***OECD, 2009).

"Physical activity includes leisure time physical activity (for example, walking, dancing, gardening, hiking, swimming), transportation (e.g. walking or cycling), occupational (i.e. work), household chores, play, games, sports or planned exercise, in the context of daily, family, and community activities" (***WHO, 2017).

In Romania with the fall of Ceaușescu's communist regime, as of March 1990, in addition to legal holidays, every person had 2 days off every month, usually on Saturday. By the end of the 
third quarter in 1990, the working week was changed to 40 hours (*** Provisional Council of National Unity, Decree-Law No. 95 of March 19, 1990). The Labor Code stipulates 14 days off for legal holidays (***Romanian Parliament, Law No. 176/2016).

Traveling in-country and abroad is no longer restricted. Furthermore, all Romanian citizens, as members of the European Union, have the right to enter any Member State solely on the basis of a valid identity card or passport (***Council Directive 2004/83/EC). This increased Romanians' free time.

Statistical research carried out in Romanian households from September 2011 to September 2012 in connection with the use of leisure time shows the following quantitative data: compared to men, women have less leisure time daily, both on days off and on working days (3.40 hours vs. 4.23 hours on working days, and 5.41 hours vs. 6.46 hours on days off). Regardless of the day of the week (working day or day off), women spend more time doing housework and caring for the family than men (on average 2.19 hours), while men work 1.03 hours more than women (***National Institute of Statistics, Press Release no. 307, 2013). Leisure time could be defined as follows: 1.Voluntary work and meeting up with friends; 2.Socializing and entertainment (socializing, entertainment and culture, rest - leisure); 3.Sports and outdoor activities; 4.Hobbies and computer use (artistic activities and hobbies, computer use, games); 5.Mass media (reading, watching television, videos and DVDs, listening to the radio, including audio tapes; 6.Other leisure activities.

Moderate- or vigorous-intensity activities were associated with longevity benefit (Arem et al., 2015). Low physical activity is involved in most chronic diseases (Booth, Roberts and Laye, 2012). Unfortunately, in Romania, the reduced time spent on physical activity appears as early as the teenage period and tends to be maintained like this later in life (Albu et al., 2016; Neagu, 2016).

Over the past 20 years, the prevalence of obesity and overweight has increased all over the world. Obesity is associated with various adverse health effects. It is a risk factor for disorders such as cardiovascular diseases, diabetes, osteoarthritis, etc. (Ng et al., 2014). Worldwide obesity has more than doubled since 1980,39\% of adults aged 18 years and over were overweight in 2014, and $13 \%$ were obese (***WHO, 2016).

"Today in western societies, sedentary behaviors tend to increase, probably due to more comfortable living conditions (air conditioning, transport, etc.), and passive leisure (television, video games, etc.). However, sedentarism is the cause of an imbalance in the energy balance because it involves a reduction in daily energy expenditure. Discrimination, stigmatization, self-blame - which are so frequent and the victims of which suffer from significant obesity - can have considerable psychological and social consequences" (Milici, 2015: 64).

\section{Objectives}

In this context, the current article aims to determine the variability of the preferred way of spending leisure time (LT), classification according to Body mass index (BMI) and the interest in the control of body weight $(\mathrm{BW})$, in relation to age, gender, place of residence and education within a Romanian sample.

\section{Material and methods}

The sample of 497 subjects, aged 35-74 years, not representative for the entire country, was randomly selected during 2011-2012 and distributed relatively equal by age groups (years), gender, place of residence and education level (Table 1). 
Table 2. Distribution of respondents according to age group, gender, place of residence, and education level

\begin{tabular}{|l|c|c|}
\hline Age groups (years) & Number & $\%$ \\
\hline $35-49$ & 173 & 34.8 \\
\hline $50-59$ & 181 & 36.4 \\
\hline $60-74$ & 143 & 28.8 \\
\hline Gender & $\mathrm{N}$ & $\%$ \\
\hline Male & 262 & 52.7 \\
\hline Female & 235 & 47.3 \\
\hline Place of residence & $\mathrm{N}$ & $\%$ \\
\hline Urban & 246 & 49.5 \\
\hline Rural & 251 & 50.5 \\
\hline Education level & $\mathrm{N}$ & $\%$ \\
\hline Low (primary education <10 years) & 146 & 29.4 \\
\hline Medium (secondary education 10-12 years) & 195 & 39.2 \\
\hline High & 156 & 31.4 \\
\hline
\end{tabular}

We have used an omnibus questionnaire of 96 items focusing on the theme of family functioning: economic, educational, cohesion-solidarity and sexual-reproductive. In the present study we shall refer to 2 items:

1) How do you spend your leisure time? Leisure time is defined as time available after you return from your place of work and on weekends, after shopping, after you have finished your housework, and at the conclusion of all daily chores. Vacation is not counted as leisure time. Respondents were offered eight categories of activity: meeting up with friends; reading books, magazines, and informal education materials (i.e., learning foreign languages); watching television or rental films, or listening to tapes and CDs; going to the theater, movies, concerts, or exhibitions; taking outdoor walks and excursions; practicing a sport; engaging in a hobby or collecting various things (e.g., stamps or coins); and other activities, such as... (Here, respondents were permitted to enter other leisure activities.) The response options for frequency of engaging in each type of activity were Often, A little, or Almost never.

2) Do you personally control your weight? The response options: Almost not at all, From time to time, Often.

The subjects have also been measured and weighted. In the present study, we shall refer also to body mass index.

The Pearson chi-square test was performed using the SPSS statistical program (version 18; SPSS Inc., Chicago, IL). Demographic variables used in the statistical analyses were: age groups (years) $(35-49,50-59,60-74)$, place of residence (urban or rural), gender (male or female) and education level (low, medium or high).

Written informed consent was obtained from each participant at recruitment. The subjects were informed that they could withdraw from the study at any stage and were ensured of confidentiality. The study was approved by the Ethics Commission of the "Francisc I. Rainer "Anthropology Institute of the Romanian Academy. 


\section{Results}

\section{Spending leisure time}

In the whole sample, most people spend "a lot of" LT watching TV, watching rented movies, listening to tapes, CDs (38.8\%), meeting friends, neighbors (26.8\%), reading books and magazines, on additional learning (such as foreign languages) (22.5), walking, outdoor trips (19.7\%). Less than $8 \%$ practice "much" a sport, go to the theater, cinema, concerts, exhibitions.

The impact of age on spending LT is obvious (Table 2). Thus, with age, it tends to increase by $15 \%$ the share of those who spend their free time meeting their friends, neighbors $(\mathrm{p}<0.01)$, with almost $20 \%$ those who spend their free time watching TV programs $(\mathrm{p}<0.001)$. With age, the proportion of those who spend their free time walking outdoors tends to decrease $(p<0.05)$ and the share of those who practice a sport tends to diminish to a half $(\mathrm{p}<0.05)$. With aging, spending the time to read books, magazines, or on additional learning (i.e., foreign languages) tends to drop ( $p>$ 0.01), and also leisure time dedicated to cinema, concerts, exhibitions decreases with over 20\% (p> 0.5). The share of those who spend time on hobbies, personal tastes, the collection of various objects (stamps, coins, etc.) tends to distribute homogeneously on age groups.

Table 2. Distribution of subjects according to spending leisure time and age groups

\begin{tabular}{|c|c|c|c|c|}
\hline \multirow[t]{2}{*}{ Spending leisure time } & \multicolumn{3}{|c|}{ Age groups (years) } & \multirow[t]{2}{*}{ Total } \\
\hline & $35-49$ & $50-59$ & $60-74$ & \\
\hline \multicolumn{5}{|c|}{ Meeting friends and neighbors } \\
\hline A little, almost never & 36.3 & 38.15 & 25.6 & 100 \\
\hline Often & 24.8 & 35.3 & 39.8 & 100 \\
\hline \multicolumn{5}{|c|}{ Reading books and magazines, informal education (i.e., learning a foreign language) } \\
\hline A little, almost never & 35.1 & 35.9 & 29 & 100 \\
\hline Often & 33.0 & 36.6 & 30.4 & 100 \\
\hline \multicolumn{5}{|c|}{ Watching television, rental films, listening to tapes, CDs } \\
\hline A little, almost never & 40.85 & 38.9 & 20.5 & 100 \\
\hline Often & 23.6 & 34.0 & 42.4 & 100 \\
\hline \multicolumn{5}{|c|}{ Going to the theater, movies, concerts, exhibitions } \\
\hline A little, almost never & 33.6 & 37.75 & 28.6 & 100 \\
\hline Often & 44.8 & 34.5 & 20.7 & 100 \\
\hline \multicolumn{5}{|c|}{ Walks, outdoor excursions } \\
\hline A little, almost never & 33.45 & 34.75 & 31.85 & 100 \\
\hline Often & 40.8 & 42.9 & 16.3 & 100 \\
\hline \multicolumn{5}{|l|}{ Practicing a sport } \\
\hline A little, almost never & 37.05 & 37.95 & 24.95 & 100 \\
\hline Often & 43.2 & 35.1 & 21.6 & 100 \\
\hline \multicolumn{5}{|c|}{ Time for a hobby, personal enjoyment, collecting (e.g., stamps or coins) } \\
\hline A little, almost never & 35.05 & 36.3 & 26.05 & 100 \\
\hline Often & 28.8 & 42.3 & 28.8 & 100 \\
\hline
\end{tabular}


Men tend more to practice a sport $(10.7 \%$ vs. 3.8\%) (p <0.01). Urban subjects spend in higher percentages "much" LT to read books, magazines, and on additional learning (i.e., foreign languages) and in lower percentages "much" LT for watching TV, rented movies, or for listening to tapes, CDs ( $<<0.001)$ (Table 3).

Table 3. Distribution of subjects according to spending leisure time and place of residence

\begin{tabular}{|l|c|c|c|}
\hline \multirow{2}{*}{ Spending leisure time } & \multicolumn{2}{|c|}{ Place of residence } & \multirow{2}{*}{ Total } \\
\cline { 2 - 3 } & Urban & Rural & \\
\hline \multicolumn{2}{|l|}{ Reading books and magazines, informal education (i.e., learning a foreign language) } \\
\hline A little, almost never & 44.4 & 55.6 & 100 \\
\hline Often & 67.0 & 33.0 & 100 \\
\hline Watching television, rental films, listening to tapes, CDs & 100 \\
\hline A little, almost never & 55.9 & 44.1 & 100 \\
\hline Often & 39.3 & 60.7 & \\
\hline
\end{tabular}

Subjects with a low level of education spend in higher percentages "much" LT meeting friends, neighbors ( $p<0.05)$, watching TV, rented films, listening to tapes, CDs ( $p<0.01)$, and those with medium and high education spend in higher percentages "much" LT to read books, magazines, and on additional learning (i.e., foreign languages) $(\mathrm{p}<0.01)$ (Table 4). Otherwise, there were no statistically significant differences or worthy to be commented upon.

Table 4. Distribution of subjects according to spending leisure time and education level

\begin{tabular}{|l|c|c|c|c|}
\hline \multirow{2}{*}{ Spending leisure time } & \multicolumn{3}{|c|}{ Education level } & \multirow{2}{*}{ Total } \\
\cline { 2 - 5 } & Low & Medium & High & \\
\hline Meeting friends and neighbors & 25.3 & 41.8 & 33.0 & 100 \\
\hline A little, almost never & 40.6 & 32.3 & 27.1 & 100 \\
\hline Often & 34.3 & 37.7 & 28.1 & 100 \\
\hline Reading books and magazines, informal education (i.e., learning a foreign language) \\
\hline A little, almost never & 12.5 & 44.6 & 42.9 & 100 \\
\hline Often & 19.6 & 45.4 & 35.0 & 100 \\
\hline Watching television, rental films, listening to tapes, CDs \\
\hline A little, almost never & 45.0 & 29.3 & 25.7 & 100 \\
\hline Often &
\end{tabular}

\section{Body mass index, body weight control}

BMI classification indicates $16.9 \%$ obese, $39.2 \%$ overweight, $43.3 \%$ normal weight, $0.6 \%$ underweight.

Regarding obesity, a peak in 50-59 age group is observed, followed by a decrease in weight $(\mathrm{p}<0.05)$, obesity is higher in the rural population $(\mathrm{p}<0.001)$ and those in the rural area $(\mathrm{p}<0.001)$. After 60 years, overweight prevails and the prevalence of the individuals with normal weight decreases after 49 years $(p>0.5)$. Overweight is higher in the case of men $(p<0.05)$, obesity is higher in the rural areas $(\mathrm{p}<0.001)$ and in the case of people with a low level of education $(\mathrm{p}<0.05)$ (Table 5). 
Table 5. Distribution of subjects according to BMI, age groups, gender, place of residence and education level

\begin{tabular}{|l|l|c|c|c|c|}
\hline \multicolumn{2}{|l|}{ Sociodemographic variables } & \multicolumn{4}{|c|}{ Classification according to BMI } \\
\cline { 3 - 6 } \multicolumn{2}{|l}{} & $\begin{array}{c}\text { Underweight } \\
(<18.5)\end{array}$ & $\begin{array}{c}\text { Normal } \\
(18.5-24.9)\end{array}$ & $\begin{array}{c}\text { Overweigh } \\
(25-29.9)\end{array}$ & $\begin{array}{c}\text { Obese } \\
(>=30)\end{array}$ \\
\hline \multirow{3}{*}{ Age groups (years) } & $35-49$ & 0.6 & 50.9 & 34.1 & 14.5 \\
\cline { 2 - 6 } & $50-59$ & 0.6 & 39.2 & 39.2 & 21.0 \\
\cline { 2 - 6 } & $60-74$ & 0.7 & 39.2 & 45.5 & 14.7 \\
\hline \multirow{3}{*}{ Gender } & Male & 0 & 41.6 & 43.9 & 14.5 \\
\cline { 2 - 6 } & Female & 1.3 & 45.1 & 34.0 & 19.6 \\
\hline \multirow{3}{*}{ Place of residence } & Urban & 0.4 & 49.6 & 40.2 & 9.8 \\
\cline { 2 - 6 } & Rural & 0.8 & 37.1 & 38.2 & 23.9 \\
\cline { 2 - 6 } & Low & 0.7 & 45.2 & 34.2 & 19.9 \\
\cline { 2 - 6 } & Medium & 1.0 & 34.9 & 47.2 & 16.9 \\
\cline { 2 - 6 } & High & 0 & 51.9 & 34.0 & 14.1 \\
\hline
\end{tabular}

Of the surveyed people $57.3 \%$ control their weight "from time to time," $28.8 \%$ "almost never" and $13.9 \%$ "often".

It has been identified that with age the proportion of people controlling BW decreases and also that women and urban subjects control their BW more frequently ( $\mathrm{p}<0.05)$. BW control was not statistically significantly influenced by the level of education, but those with a medium level of education tend to do it more often (Table 6).

Table 6. Distribution of subjects according to body weight control, age groups, gender, place of residence and education level

\begin{tabular}{|c|c|c|c|c|}
\hline \multirow{2}{*}{\multicolumn{2}{|c|}{ Sociodemographic variables }} & \multicolumn{3}{|c|}{ Body weight control } \\
\hline & & Almost never & From time to time & Often \\
\hline \multirow[t]{3}{*}{ Age groups (years) } & $35-49$ & 27.3 & 36.8 & 42.0 \\
\hline & $50-59$ & 35.0 & 36.5 & 39.1 \\
\hline & $60-74$ & 37.8 & 26.7 & 18.8 \\
\hline \multirow[t]{2}{*}{ Gender } & Male & 60.8 & 51.9 & 39.1 \\
\hline & Female & 39.2 & 48.1 & 60.9 \\
\hline \multirow[t]{2}{*}{ Place of residence } & Urban & 39.2 & 51.6 & 62.3 \\
\hline & Rural & 60.8 & 48.4 & 37.7 \\
\hline \multirow[t]{3}{*}{ Education level } & Low & 79.7 & 73.0 & 66.7 \\
\hline & Medium & 17.5 & 19.3 & 23.2 \\
\hline & High & 2.8 & 7.7 & 10.1 \\
\hline
\end{tabular}

Those who spend LT practicing a sport monitor their BW to a higher extent $(\mathrm{p}<0.01)$. BMI category was not correlated with the way of spending LT. 


\section{Discussions}

Like in the American Survey of 2014, it has been identified that spending LT watching TV prevails, that the older people spend more LT this way in comparison to young people and that men are more likely than women to participate in sports, exercise (***United States Department of Labor, Bureau of Labor Statistics, 2014).

Hamer et al. have found that the sedentary pattern at midlife continues to early old age (Hamer, Kivimaki, and Steptoe, 2012). Van der Berg and collaborators have found that several aspects from the midlife such as unmarried, poorer housing, obesity, and heart disease were correlated with more sedentary time per day in old age (van der Berg et al., 2014). The current study has revealed that the decrease of the physical activity begins after 49 years and after 60 years the activities involving physical activity diminish even more.

Although the majority of the rural population performs agricultural activities that involve physical effort and energy consumption, the proportion of obesity is higher in the rural area, which means that other variables are involved, such as overfeeding with pasta or bread.

The possibilities to spend LT in the rural areas are limited and this explains the almost double amount of people who spend their LT watching TV.

Our study suggests, like the Canadian one of 2007 (Ashe et al., 2009), that older Romanians are not active enough.

The higher percentage of obesity in 50-59 age group and of overweight beginning with the age of 60 suggests that weight gain rises with age and at the same time that the prevalence of obesity increases with age to peak at about 60 years. The same situation was noticed in other researches such as those in the United Kingdom, (Gulland, 2010), USA (Villareal et al., 2005), or Sweden (Kuskowska-Wolk and Rossner, 1990).

Studies show that menopause is associated with weight gain and especially with abdominal obesity (***The North American Menopause Society, 2012; Dubnov-Raz, Pines and Berry, 2007; Gravena et al., 2013). Yet, as in the UK (***The National Institute for Health Research (NIHR), Dissemination Centre, 2015) in the studied sample more men than women are overweight and the interest for the control of BW is higher in the case of women.

Among the 19 EU Member States, there was no systematic difference between the sexes as regards the share of obese women and men in 2008. A higher proportion of men (than women) were overweight in each of the EU Member States (Eurostat Statistics Explained, 2008). Our study has found out that obesity is higher in the case of men compared with women. Similar results have been reached in Ireland (Leahy et al., 2014) and Serbia - Vojvodina province (Pavlica, Bozic-Krstic and Rakic, 2010). Different data have been found in the USA where the prevalence of obesity among women was higher than among men (Ogden et al., 2015).

More studies are necessary to understand why it was not statistically significantly confirmed, but only as a tendency, the fact that people who have more physical activities have rather normal weight.

In a cohort of middle-aged active employees, Pulsford et al. have found that self-reported time spent watching TV per week was associated with Obesity (Pulsford et al., 2013). Ekelund et al. have found in 393 middle-aged healthy whites that BMI, fat mass, and waist circumference may predict the sedentary time, but sedentary time does not predict future obesity (Ekelund et al., 2008). More research is needed to identify why overweight and obesity in the present study have not statistically correlated with spending time watching TV. 
Preventing obesity in the elderly should be a target because obesity is involved in the decline in age-related physical functioning.

The impact of aging on leisure time and body weight is obvious, as subjects in the sample older than 50 years are more sedentary and less interested in body weight, while normal weight decreases. Due to the fact that the sample was small and the share of those practicing a sport was very low, there was no significant correlation between BMI and leisure time. This is a limit of this article.

\section{Conclusions}

In promoting educational programs for a healthy lifestyle (nutrition, physical movement), messages should be individualized according to socio-demographic characteristics and specific motivations throughout family life cycles. This study has identified that spending LT is primarily influenced by age, then by the level of education and in the last place by residence, and that BMI is primarily influenced by age, gender, place of residence, and then by the level of education. Thus, the most important variable in promoting public health programs is age.

In the case of young people, to encourage physical activity, the success would be greater by focusing on its advantages in the body weight management, as it is known their preoccupation, especially in the case of girls, for the appearance of their body. The focus should be also on highlighting the benefits of outdoor movement for school performance.

In the elderly, it should be stressed that regular physical activity may be an important potential protective factor against cognitive decline and against cardiovascular diseases. Greater efforts are needed to raise interest and energy for physical activity in the case of elderly.

These low percentages of leisure-time physical activity require urgent actions.

\section{Acknowledgments}

The subjects within the sample group belong to "The identitary values of the contemporary Romanian family in the framework of the globalization. An anthropological approach" research, By Cornelia Rada, financially supported by the European Social Fund, Sectoral Operational Programme for Human Resources Development, 2007-2013, within the project "Turning to account the Cultural Identities in the global processes" Contract POSDRU/89/1.5/S/59758/2011-2013. This article is a result of the joint project "Expanding research on family in Poland and Romania" carried out by Rafal Smoczynski from the Polish Academy of Sciences and Cornelia Rada from the Romanian Academy.

\section{Bibliography}

1. Albu, A., Onose, I., Negrea, M., Cracana, I. and Hodorca, R.M., 2016. Correlation between physical diagnostic and exercise in a group of teens grom Garabet Ibraileanu high school of Iasi. The European Proceedings of Social \& Behavioural Sciences, vol XI, pp.273-279.

2. Arem H., Moore, S.C., Patel, A., Hartge, P., Berrington de Gonzalez, A., Visvanathan, K., Campbell, P.T., Freedman, M., Weiderpass, E., Adami, H.O., Linet, M.S., Lee, I.M., Matthews, C.E., 2015. Leisure time physical activity and mortality: a detailed pooled analysis of the dose- 
response relationship. JAMA Internal Medicine, 175(6), pp.959-67. doi: 10.1001/jamainternmed.2015.0533.

3. Ashe, M.C., Miller, W.C., Eng, J.J., Noreau, L., Physical Activity and Chronic Conditions Research Team, 2009. Older adults, chronic disease and leisure-time physical activity. Gerontology, 55(1), pp.64-72. doi: 10.1159/000141518. Epub 2008 Jun 20.

4. Booth, F.W., Roberts, C. K., and Matthew J.L., 2012. Lack of exercise is a major cause of chronic diseases. Comprehensive Physiology, 2(2), pp.1143-1211. doi: 10.1002/cphy.c110025.

5. Dubnov-Raz, G., Pines, A., Berry, E.M., 2007. Diet and lifestyle in managing postmenopausal obesity. Climacteric, 10(2), pp.38-41.

6. Ekelund, U., Brage, S., Besson, H., Sharp, S., Wareham, N.J., 2008. Time spent being sedentary and weight gain in healthy adults: reverse or bidirectional causality? American Journal of Clinical Nutrition, 88, pp.612-7.

7. Gravena, A.A., Brischiliari, S.C., Lopes, T.C., Agnolo, C.M., Carvalho M.D., and Pelloso, S.M., 2013. Excess weight and abdominal obesity in postmenopausal Brazilian women: a populationbased study. BMC Women's Health, 13, p.46, doi: 10.1186/1472-6874-13-46.

8. Gulland, A., 2010. Obesity among over 65s in UK reflects "lifetime of gaining weight", British Medical Journal, 341:c3585. doi: 10.1136/bmj.c3585.

9. Hamer, M., Kivimaki, M., Steptoe, A., 2012. Longitudinal patterns in physical activity and sedentary behaviour from mid-life to early old age: a substudy of the Whitehall II cohort. Journal of Epidemiology and Community Health, 66(12), pp.1110-5.

10. Kuskowska-Wolk, A., Rossner, S., 1990. Body mass distribution of a representative adult population in Sweden. Diabetes Research and Clinical Practice, 10(suppl), S37-S41.

11. Leahy, S., Nolan, A., O'Connell, J., Kenny, R.A., 2014. Obesity in an Ageing Society: Implications for health, physical function and health service utilization. Dublin: TCD. Available at: <http://tilda.tcd.ie/assets/pdf/Obesity in an Ageing Society Report.pdf.> [Accessed 4 May 2016].

12. Milici, N., 2015. Sindromul metabolic şi obezitatea. Perspective antropologice (Metabolic syndrome and the obesity. Anthropological perspectives), Bucureşti: Editura Academiei Române.

13. Neagu, A., 2016. Les pressions liées à l'apparence et la gestion du poids dans un échantillon des adolescents de Bucarest (Appearance - related pressures and weight management in an adolescent sample from Bucharest). In : III Colloque International Francophone „Mondialisation des comportements alimentaires et facteurs de risques pour l'obésité et le diabète”, pp.81-92, Sofia : Simel Press Edt.

14. Ng, M., Fleming, T., Robinson, M., Thomson, B., Graetz, N., Margono, C., Mullany, E.C., Biryukov, S., Abbafati, C., Abera, S.F., Abraham, J.P., Abu-Rmeileh, N.M., Achoki, T., AlBuhairan, F.S., Alemu, Z.A., Alfonso, R., Ali, M.K., Ali, R., Guzman, N.A., Ammar, W., Anwari, P., Banerjee, A., Barquera, S., Basu, S., Bennett, D.A., Bhutta, Z., Blore, J., Cabral, N., Nonato, I.C., Chang, J.C., Chowdhury, R., Courville, K.J., Criqui, M.H., Cundiff, D.K., Dabhadkar, K.C., Dandona, L., Davis, A., Dayama, A., Dharmaratne, S.D., Ding, E.L,, Durrani, A.M., Esteghamati, A., Farzadfar, F., Fay, D.F., Feigin, V.L., Flaxman, A., Forouzanfar, M.H., Goto, A., Green, M.A., Gupta, R., Hafezi-Nejad, N., Hankey, G.J., Harewood, H.C., Havmoeller, R., Hay, S., Hernandez, L., Husseini, A., Idrisov, B.T., Ikeda, N., Islami, F., Jahangir, E., Jassal, S.K., Jee, S.H., Jeffreys, M., Jonas, J.B., Kabagambe, E.K., Khalifa, S.E., Kengne, A.P., Khader, Y.S., Khang, Y.H., Kim, D., Kimokoti, R.W., Kinge, J.M., Kokubo, Y., Kosen, S., Kwan, G., Lai, T., Leinsalu, M., Li, Y., Liang, X., Liu, S., Logroscino, G., Lotufo, 
P.A., Lu, Y., Ma, J., Mainoo, N.K., Mensah, G.A., Merriman, T.R., Mokdad, A.H., Moschandreas, J., Naghavi, M., Naheed, A., Nand, D., Narayan, K.M., Nelson, E.L., Neuhouser, M.L., Nisar, M.I., Ohkubo, T., Oti, S.O., Pedroza, A., Prabhakaran, D., Roy, N., Sampson, U., Seo, H., Sepanlou, S.G., Shibuya, K., Shiri, R., Shiue, I., Singh, G.M., Singh, J.A., Skirbekk, V., Stapelberg, N.J., Sturua, L., Sykes, B.L., Tobias, M., Tran, B.X., Trasande, L., Toyoshima, H., van de Vijver, S., Vasankari, T.J., Veerman, J.L., Velasquez-Melendez, G., Vlassov, V.V., Vollset, S.E., Vos, T., Wang, C., Wang, X., Weiderpass, E., Werdecker, A., Wright, J.L., Yang, Y.C., Yatsuya, H., Yoon, J., Yoon, S.J., Zhao, Y., Zhou, M., Zhu, S., Lopez, A.D., Murray, C.J., Gakidou, E., 2014. Global, regional, and national prevalence of overweight and obesity in children and adults during 1980-2013: a systematic analysis for the Global Burden of Disease Study 2013. Lancet. 384(9945), pp.766-81. doi: 10.1016/S0140-6736(14)60460-8.

15. van der Berg, J.D., Bosma, H., Caserotti, P., Eiriksdottir, G., Arnardottir, N.Y., Martin, K.R., Brychta, R. J., Chen, K.Y., Sveinsson, T., Johannsson, E., Launer, L.J., Gudnason, V., Jonsson, P.V., Stehouwer, C.D., Harris, T.B., and Koster, A., 2014. Midlife Determinants Associated with Sedentary Behavior in Old Age. Medicine and science in sports and exercise, 46(7), pp.1359136.

16. Ogden, C.L., Carroll, M.D., Fryar C.D., and Flegal K.M., 2015. Prevalence of Obesity Among Adults and Youth: United States, 2011-2014. National Center for Health Statistics (NCHS) Data Brief. 219, pp.1-8. Available at: <https://www.cdc.gov/nchs/products/databriefs/db219.htm> [Accessed 22 April 2017].

17. Pavlica, T., Bozic-Krstic, V. \& Rakic, R., 2010. Body mass index, waist-to-hip ratio and waist/height in adult population from Backa and Banat - the Republic of Serbia. Annals of Human Biology, 37(4), pp.562-573.

18. Pulsford, R.M., Stamatakis, E., Britton, A.R., Brunner, E.J., Hillsdon, M.M., 2013. Sitting behavior and obesity: evidence from the Whitehall II study. American Journal of Preventive Medicine, 44(2), pp.132-138.

19. Villareal, D., Apovian, C., Kushner, R., \& Klein, S., 2005. Obesity in older adults: technical Review and position statement of the American Society for Nutrition and NAASO, The Obesity Society. American Journal of Clinical Nutrition, 82(5), pp.923-934. Available at: <www.ajcn.org/cgi/content/full/82/5/923> [Accessed 19 October 2008].

20. ***Consiliul Provizoriu de Uniune Natională (CPUN), 1990. Decret-Lege nr. 95 din 14 martie 1990 privind trecerea la săptămâna de lucru de 5 zile în unităţile de stat (Provisional Council of National Unity, Decree-Law No. 95 of March 19, 1990 on passing to the 5-day working week in the state units). București: Monitorul Oficial nr.36, 19 martie.

21. *** Directiva Parlamentului European şi a Consiliului 2004/38/CE privind dreptul la liberă circulaţie şi şedere pe teritoriul statelor membre pentru cetăţenii Uniunii şi membrii familiilor acestora (European Parliament and Council Directive 2004/38/EC on the right of citizens of the Union and their family members to move and reside freely within the territory of the Member States) Available at: 〈http://eur-lex.europa.eu/legal-content/RO/TXT/?uri=celex:32004L0038> [Accessed12 June 2013].

22. ***Eurostat Statistics Explained, 2008. Overweight and obesity - BMI statistics (online) Available at: <http://ec.europa.eu/eurostat/statisticsexplained/index.php/Overweight_and_obesity___BMI_statistics > [Accessed 24 April 2017].

23. ***Institutul Naţional de Statistică, Comunicat de presă Nr. 307 din 20 decembrie 2013 (National Institute of Statistics, Press Release no. 307 of 2013). Available at: < 
http://www.insse.ro/cms/files/statistici/comunicate/com_anuale/util_timpul/utilizarea_timpului_r 13.pdf > [Accessed 11 May 2017].

24. *** Parlamentul României, 2016. Legea nr. 176/2016 pentru modificarea alin. (1) al art. 139 din Legea nr. 53/2003 - Codul muncii (Romanian Parliament, Law No. 176/2016 for the amendment to paragraph 1 of art. 139 of the Law no. 53/2003 - Labor Code). Available at: <http://www.codulmuncii.ro/titlul_3/capitolul_2/sectiunea_3_1.html> [Accessed 22 April 2017].

25. ***The National Institute for Health Research (NIHR), Dissemination Centre, 2015. What motivates men to lose weight? Available at: <http://www.dc.nihr.ac.uk/highlights/obesity-inmen/what-motivates-men-to-lose-weight.htm.> [Accessed 11 March 2017].

26. ***The North American Menopause Society (NAMS), 2012. Menopause Guidebook. 7th Edition. Available at: <http://www.menopause.org/publications/consumer-publications/-emmenopause-guidebook-em-7th-edition> [Accessed 20 June 2013].

27. ***The Organisation for Economic Co-operation and Development (OECD), 2009. Special Focus: Measuring Leisure in OECD Countries. In: OECD, Society at a Glance 2009: OECD Social Indicators. OECD Publishing. Available at: <http://www.oecd.org/berlin/42675407.pdf > [Accessed 24 March 2013].

28. ***United States Department of Labor, Bureau of Labor Statistics, 2014. American Time Use Survey. Available at: <http://www.bls.gov/TUS/CHARTS/LEISURE.HTM> [Accessed 4 May 2017].

29. *** World Health Organization (WHO), 2016. Obesity and overweight. Fact sheet. Available at: $<$ http://www.who.int/mediacentre/factsheets/fs311/en/> [Accessed 19 April 2017].

30. ***World Health Organization (WHO), 2017. Global Strategy on Diet, Physical Activity and Health, Physical Activity Adults. Available at: <http://www.who.int/dietphysicalactivity/factsheet_adults/en/> [Accessed 12 May 2017]. 